\title{
Issues of eLogistics applications for varying stakeholders: findings from an online survey
}

\author{
Dewan Md Zahurul Islam • Thomas H. Zunder
}

Received: 19 August 2010 / Accepted: 1 February 2013 /Published online: 24 February 2013

(C) The Author(s) 2013. This article is published with open access at SpringerLink.com

\begin{abstract}
Purpose The current paper aims to: a) propose and verify definition of eLogistics: 'a set of activities based on using ICT systems and tools, as well as the Internet, as the main communication medium in order to maintain logistics processes' and explore its acceptance; b) provide a synthesis of trend and possibilities of eLogistics systems and c) obtain a comprehensive picture of available eLogistics applications, sources, functionality and use by different type of companies.

Method A qualitative research approach was adopted applying the Bristol Online Survey (BOS) tool. A brief literature review (of limited online sources and books) resulted in the online survey questionnaire. The survey questions had the options of: agree or disagree; or yes or no on a particular statement or issue. Also to solicit the opinion of the survey participants, a free text area/box was provided against an issue or statement.

Result The study suggests that open source, open standards and standardised system interfaces will support increased supply chain efficiency through integration and access to SMEs as well as larger players.

Conclusion The development and running of an eLogistics platform is costly for SMEs. The authors recommend that such platform be developed through funding by national governments and/or the European Commission. The running and maintenance of such platform can be done by an association relevant to SMEs or a third party with a small contribution (or fee) by the participating SMEs.
\end{abstract}

Electronic supplementary material The online version of this article (doi:10.1007/s12544-013-0093-1) contains supplementary material, which is available to authorized users.

D. M. Z. Islam $(\varangle) \cdot$ T. H. Zunder

Freight Logistics Research Group, Centre for Railway Research,

University of Newcastle Upon Tyne, Newcastle Upon Tyne NE1

7RU, UK

e-mail: dewan.islam@newcastle.ac.uk
Keywords eLogistics system · SMEs · Open standard · Open source $\cdot$ Platform

\section{Introduction}

eLogistics refers to the usage of Information and Communication Technology (ICT) in the logistics processes of internal and external supply chains. The term has been widely used in EC policy documents and Framework Programme seven first research calls. It is not clear if the term has wide acceptance and is written in many different ways (e.g. E-logistics, e-Logistics, eLogistics, Elogistics). This paper adopts the terminology 'eLogistics'.

Although the usage of ICT is not new any more, a review of online sources suggests a little use of the term eLogistics: this may indicate the recent emergence of eLogistics, or that is simply not in common parlance outside the European Commission. Also, some recent books such as $[8,10,11]$ that are highly referred in taught courses in logistics and supply chain management fields have not yet included eLogistics. [10] discusses e-commerce, e-fulfilment, eprocurement, e-tailing; [8] discusses e-procurement and [11] discusses e-commerce. The definitions, largely from online source (e.g. [3, 4, 14]), equate e-commerce to eLogistics, and vice versa, as they show eLogistics as an external economic transaction realized electronically (online references). But the current research does not equate e-commerce with eLogistics, even though they have numerous overlaps functionally and systematically. The data flows in the basic and supporting logistics processes between supply chain partners and inside a company can be defined as eLogistics.

The current research proposes a definition of eLogistics as 'a set of activities based on using ICT systems and tools, as well as the Internet, as the main communication medium in order to maintain logistics processes'. This definition was 
developed by the authors (as a partner in the KOMODA consortium) through discussions first with the KOMODA project [7] partners and subsequent interviews with external experts. This paper examines the degree to which the definition is accepted by logistics experts and whether it is widely used in the sector.

A literature review (books and online sources) was conducted that suggested that the logistics service related data flows include ordering, inventory management, transporting, co-packing, co-manufacturing, vendor managed inventory (VMI), supplier managed inventory (SMI), planning, distribution, etc. Whilst large companies have either developed bespoke applications or platforms or have invested in 'off the shelf' solutions, many small and medium-sized enterprise (SMEs) may not have the financial and technical resources and abilities to implement and maintain such a system.

The literature review further suggested that there is a research gap in identifying the eLogistics related issues for SMEs that includes freight logistics service providers and users. The current research addresses this research gap with an online survey among the stakeholders.

To address the research gap, the current paper aims to: a) verify the proposed definition of eLogistics and its acceptance; b) provide a synthetic view of trend and possibilities of eLogistics systems and c) obtain a comprehensive picture of available eLogistics applications, sources, functionality and use by different type of companies.

\section{Research approach}

In line with the research objectives, a qualitative research approach was adopted. The respondents were given options: agree or disagree; or yes or no. To solicit the opinion of the stakeholders a brief literature review (on limited online sources and books) resulted in a draft survey questionnaire for an online survey. As an increasing number of surveys in different fields are conducted using Internet, although it has some advantage (e.g. no or minimum cost, fast, reliable, easy to fill by the participants) and disadvantage (many people delete the online survey without opening it, fear of spam or virus). The draft questionnaire was consulted in a meeting participated by some 12 experts (from KOMODA project partners and consultation board members of the KOMODA project) in the field. The questionnaire was then tested online with some external experts. The Bristol Online Survey (BOS) tool was used for this research. The data was extracted from the BOS [1] and analysed using Microsoft Office excel.
2.1 Research questionnaire

To explore the varying or similar views on an issue, the questionnaire included investigations of stakeholders' profile in terms of:

SME and Non-SME to explore their varying opinion; Transport mode use (Road, Rail, Maritime, Inland waterways - IWW, Air, Intermodal) to explore the variation of opinion among the modal participants;

Company involvement in the provision or regulation of freight transport and logistics (Transport and Logistics Service Provider-TLSP, Shipper, Academic and Researcher and Authorities) to explore the variation of opinion among the provision or regulation of transport and logistics services;

Expertise in ICT (basic understanding, competent user, expert and none) to explore the variation of opinion due to the level of expertise in ICT; and

Geographical coverage (Central, Northern, Southern, Western European and non-European) of company operation to explore whether there is a variation in opinion due to the geographical variation.

A large number of freight logistics service providers and users are SMEs. So it is vital to explore their views. The authors consider that the views may differ according to the user of transport modes. The authors have included company involvement in the provision or regulation of freight transport and logistics service to explore whether there is any differing opinion. Similarly the authors have included expertise in ICT and Geographical coverage of company operation to explore where there are any differing views or not.

The main research questions were in three categories. The first category was the 'eLogistics definition' which was divided into three sub-questions:

a) Agreement or disagreement on the given definition,

b) Applicability of the definition in the freight transport and logistics sector, and

c) Understanding of eLogistics in the freight transport sector.

The authors have included these research questions as there is no precise definition of eLogistics. The authors are aware that the definition may not be perfect. So the authors have included a test question: whether this definition is widely applicable in the freight logistics sector or not. The authors also want to verify the understanding of the terminology 'eLogistics' (whether poor or not) in the freight transport sector.

The second category research questions or statements were on exploring the 'Trends and Possibilities' of eLogistics systems. There were the following eight statements to 
explore the degree of agreement or disagreement on the trends and possibilities.

Standardised eLogistics system interfaces can increase efficiency along the supply chain;

In a fragmented market like road freight open standards will allow integration;

Open source will allow smaller companies access to better quality eLogistics application;

It is too difficult to integrate multiple modes of transport in ICT;

Small operators will be forced to use bigger operators' ICT systems;

Integration between rail operators will be easier since there are fewer actors;

German ICT will dominate eLogistics in Europe as German logistics continues to dominate;

Rail is so monolithic that ICT integration with other modes will fail

The respondents were requested to add comments against each statement to generate further research questions. The authors have included the statements on trend and possibilities of eLogistics systems as a preliminary step. The questionnaire included a room to collect the opinions of the participants to explore in the next research.

The third category question included thirteen functional areas, identified through literature reviews, of eLogistics application. The functional areas are: order management systems, booking (customs, carriers), invoicing systems, cargo monitoring systems, vehicle tracking and tracing systems, route guidance systems (global positioning system GPS), multimodal route planning, terminal operations optimisation systems, transport statistics and assessment systems, transport resource allocation (fleet management systems), decision support systems, electronic data interchange and
e-Commerce applications. The participants were asked their opinion on the following three issues:

Whether the eLogistics applications are used or not; What is the origin of the application?

Four options: proprietary package, in-house, open source and unknown, and

What is the hardware platform?

Five options: own hardware, supplier hardware, third party hardware, internet platform and unknown.

The authors understand that there may be more eLogistics functional areas. Thus the questionnaire included a room to collect additional functional areas of eLogistics applications.

\subsection{Sample}

First about 1,000 global 'potential respondents' were identified from different sources such as participants in the near past conferences/seminars held in Europe in relevant field, KOMODA project partners own data sources. They were requested to participate, by email, from 15th August to 30th December 2008. The potential respondent's pool was drawn from the experts and practitioners in the logistics, ICT sectors, academia and consultancy to understand the varying or similar views on the research questions.

A total of 99 responses were received of which 17 were invalid due to duplications and missing of essential information. So, the total number of valid response was 82 (response rate about $8.2 \%$ ) of which ten are from outside EU-27 (from Australia, Mexico, Norway, Serbia and Turkey) (see Graph 1). The majority of the respondents belonged to SMEs, however $38.64 \%$ of all SMEs were

\section{Country wise number of participants in the online survey}

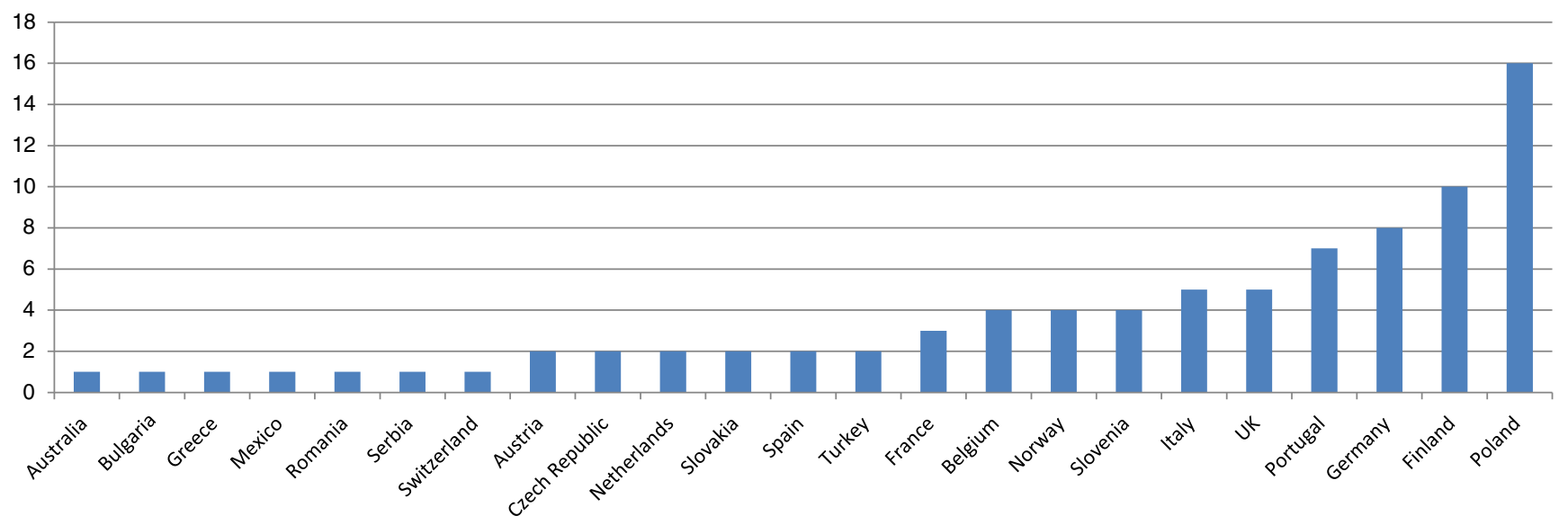

Graph 1 Country wise number of participants in the Bristol Online Survey 
academics, researcher/consultant and authorities, and $32.53 \%$ of the whole responses came from academics and researchers/consultants. In many research, comparatively a fewer number of practitioners, as they are busy with practical day to day works, take part in the survey, although in our research work there was a reasonable proportion of such participation. This was possible through different efforts including extension of time, multiple requests, publishing the survey tool in different websites and requests different public gatherings (e.g. seminars, conferences). The highest number of participants was from operational management level followed by senior management and very senior management. The understanding and experience level of the participants are shown in Graph 2 where only $17 \%$ had basic understanding/experience and the remaining were competent or expert level. About a half of the survey participants were competent with ICT, which is depicted on Graph 3.

\section{Major findings}

The authors discuss the findings in three main sections: opinion on the definition of eLogistics; trend and possibilities of eLogistics systems; and eLogistics applications. For the research finding purposes, four levels of majority agreement/disagreement are considered; 'simple majority', 'significant majority', 'vast majority', and 'full agreement' that are defined below:

'Simple majority' if the consensus range is more than $50 \%$ and up to $70 \%$;

'Significant majority' if the consensus range is more than $70 \%$ but less than $85 \%$; and

'Vast majority' if the consensus range is equal to or higher than $85 \%$ but less than $100 \%$; and

Full majority if there is $100 \%$ agreement or disagreement views.

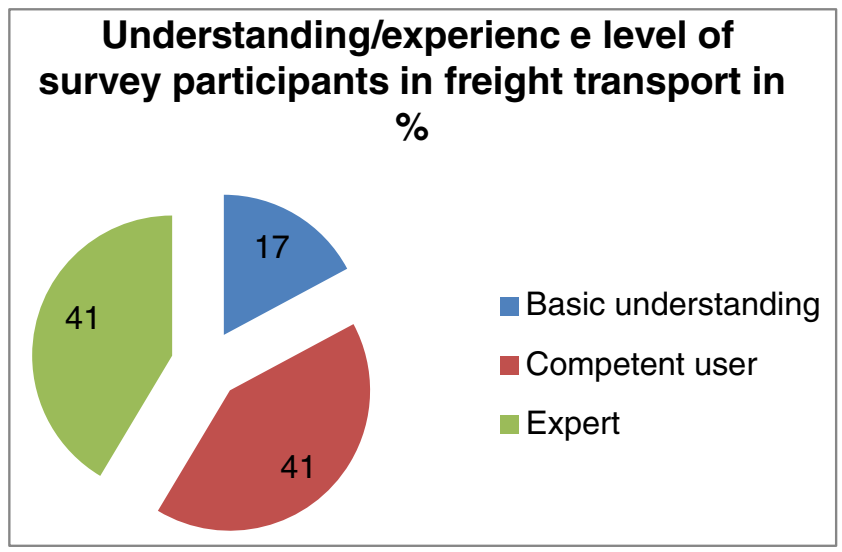

Graph 2 Understanding/ experience level of survey participants in freight transport

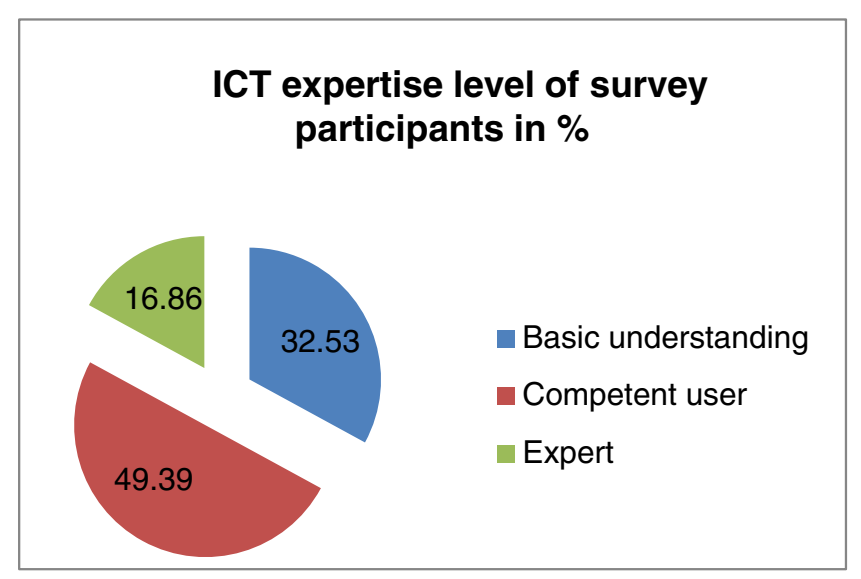

Graph 3 ICT expertise level of survey participants in per cent

3.1 Opinion on the definition of eLogistics

\subsubsection{General findings}

A vast majority of the participants agreed with the definition (see Table 1). They also agreed in a vast majority with the notion that this definition was widely applicability. There is a simple majority agreement with the notion that eLogistics is poorly understood or defined in the freight transport and logistics sector. There are some differences among different types of participants that are discussed below.

\subsubsection{SMEs versus Non-SMEs}

In this section the authors discuss whether there are any differing views on the definition and its applicability between the SME and the Non-SME sub-groups. The authors find that there is not much difference (see Table 2) as both had a vast majority agreement with the definition. But they differed on the notion that 'This definition is widely applicable in the freight and logistics sector'. Although the SMEs have a vast majority agreement, the Non-SMEs had a significant majority agreement. Both groups had a simple majority agreement on the notion 'eLogistics is poorly understood or defined in the freight transport and logistics sector'. Overall, the authors find that both sub-groups represent nearer views on the definition and understanding of eLogistics systems.

\subsubsection{Provision or regulation of freight transport}

In this section the authors discuss whether there is any differing view on the definition and its applicability among the subgroups: TLSP, Terminal Operator, Shipper, AcademicResearcher and Authorities and find that there are some differences (see Table 2) among the sub-groups. For example, the TLSP, the Shipper, and the Academic-Researcher sub-groups had a vast majority agreement with the definition and the 
Table 1 The definition of the eLogistics: general opinion

\begin{tabular}{lccc}
\hline $\begin{array}{l}\text { Agreement / } \\
\text { Disagreement }\end{array}$ & $\begin{array}{l}\text { I agree with } \\
\text { the definition }\end{array}$ & $\begin{array}{l}\text { This definition is widely } \\
\text { applicable in the freight } \\
\text { and logistics sector }\end{array}$ & $\begin{array}{l}\text { eLogistics is poorly understood } \\
\text { or defined in the freight and } \\
\text { logistics sector }\end{array}$ \\
\hline Agree & $64(89 \%)$ & $63(87 \%)$ & $47(66 \%)$ \\
Disagree & $9(11 \%)$ & $9(13 \%)$ & $24(34 \%)$ \\
Total & $72(100 \%)$ & $72(100 \%)$ & $71(100 \%)$ \\
\hline
\end{tabular}

Terminal Operator sub-group had a significant majority agreement whereas the Authorities sub-group had a simple majority disagreement with the definition.

In terms of the wide applicability of the definition, the TLSP, the Academic-Researcher, the Shipper and the Authorities sub-groups had a higher level of majority agreement (significant, vast, vast and full respectively). It can be noted here that the vast majority agreement of the Authorities sub-group is contradictory to the previous views on the definition. On the other hand, the Terminal Operator subgroup had a lower level (simple) of majority agreement.

The authors find that although the notion 'eLogistics is poorly understood or defined in the freight transport and logistics sector' achieved a simple majority, there some differences among the sub-groups. For example, the Southern EU and the Non-EU participants were divided on the notion.

\subsubsection{Geographical opinion}

In this section the authors discuss whether there are any differing views on the definition and its applicability according to the five regional participants: Western EU, Southern EU, Northern EU, Central EU and Non-EU. It can be noted here that the authors did not define these five European subgroups as to which European countries belong to which subgroup. Rather the authors relied on the perception of the participants as to which sub-group they below to. The authors find that there are some differences (see Table 2) among the five sub-groups. The Northern EU had a simple majority agreement; the Central-EU had a vast majority agreement whereas the remaining groups have a full majority agreement. There was no majority disagreement or divided opinion.

On the other hand, in terms of the 'wide applicability of the definition', the Non-EU, Southern-EU and Western-EU groups have full agreements; and the Central-EU group has a vast majority whereas the Northern-EU group has a significant majority agreement.

Although the notion 'eLogistics is poorly understood or defined in the freight transport and logistics sector' achieved a simple majority, the authors find that there are some differences among the sub-groups. The Southern EU and the Non-EU sub-groups had a divided opinion and the remaining sub-groups had a simple majority agreement.

\subsubsection{ICT expertise wise opinion}

In this section the authors discuss whether there are any differing views on the definition and its applicability among the three ICT sub-groups: ICT-Basic, ICT-Competent and ICT-Expert. The authors find that there are minor differences (see Table 2), as the ICT-Basic sub-groups had a significant majority agreement with the definition. The remaining two sub-groups had a vast majority agreement. Their views were similar in terms of wide applicability of the definition. Similarly there is a minor difference of opinion (simple majority agreement) on the notion that eLogistics is poorly understood or defined in the freight transport and logistics sector. The ICT-Basic sub-groups had a significant majority agreement with the definition. The remaining two sub-groups had a simple majority agreement. The authors find that the participants with higher knowledge and skill in ICT had nearer views.

\subsection{Trends and possibilities of eLogistics systems}

The findings on the statements are discussed below. It can be noted here that the number of participants of the Shipper and the Authority sub-groups were negligible. So, their opinions are omitted in Tables 3, 4 and 5.

\subsubsection{Vast majority agreements}

In this section the authors discuss whether there is any differing views on the statement 'Open source will allow smaller companies access to better quality applications'. The authors find that there are some differences among the sub-groups (see Table 3). For example, the SMEs had a full agreement whereas the Non-SMEs had a vast majority agreement. The TLSP sub-group had a full agreement; the Academic-Researcher sub-groups had a vast majority agreement whereas the Terminal Operator had a significant majority agreement. There are some differences among the Geographical sub-groups. The Southern EU and the NonEU sub-groups had similar views (full agreement); the Western EU sub-group had a bit lower level of (significant majority) agreement and the remaining sub-groups had a vast majority agreement. There are some differences among the ICT sub-groups. The ICT-Basic and the ICT-Competent 
Table 2 Definition and understanding of eLogistics: varying views

\begin{tabular}{|c|c|c|c|}
\hline \multirow[b]{2}{*}{ Participants sub-groups } & \multicolumn{3}{|c|}{$\begin{array}{l}\text { eLogistics can be defined as 'a set of activities based on using ICT systems and tools, as well as the } \\
\text { Internet, as the main communication medium in order to maintain logistics processes' }\end{array}$} \\
\hline & I agree with the definition & $\begin{array}{l}\text { This definition is widely applicable in } \\
\text { the freight and logistics sector }\end{array}$ & $\begin{array}{l}\text { eLogistics is poorly understood or defined in } \\
\text { the freight and logistics sector }\end{array}$ \\
\hline General & $\Leftrightarrow$ & $\Leftrightarrow$ & हो \\
\hline SME (26) & हो & हो & हो \\
\hline Non-SME (21) & हो हो हो & हो हो & हो \\
\hline Road (37) & हो & हो हो हो & $\Leftrightarrow$ \\
\hline Rail (19) & हो & हो & हो \\
\hline Maritime (15) & हो & हो & हो \\
\hline IWW (5) & हो & हो & हो \\
\hline Air (14) & हो & हो हो हो & हो \\
\hline Intermodal (38) & हो हो है हो & $\Leftrightarrow$ & हो \\
\hline Shipper (3) & हो हो & हो हो हो हो & हो \\
\hline TLSP (35) & हो हो हो & $\Leftrightarrow$ & हो) \\
\hline Terminal Operator (9) & $\Leftrightarrow$ & $\Leftrightarrow$ & हो \\
\hline Academic-Researcher (22) & $\Leftrightarrow$ हो & $\Leftrightarrow$ & $\Leftrightarrow$ \\
\hline Authorities (3) & 但 & हो हो हो & हो \\
\hline Western EU (13) & $\Leftrightarrow$ हो & $\Leftrightarrow$ हो & हो हो \\
\hline Southern EU (6) & हो हो हो & हो & $\Leftrightarrow$ \\
\hline Northern EU (16) & हो) & $\Leftrightarrow$ & $\Leftrightarrow$ \\
\hline Central EU (33) & हो & हो & हो \\
\hline Non-EU (6) & हो हो हो हो & हो हो हो & $\Leftrightarrow$ \\
\hline ICT-Basic (26) & हो & हो हो हो & हो \\
\hline ICT-Competent (35) & हो हो हो & हो हो हो & $\Leftrightarrow$ \\
\hline ICT-Expert (10) & हो हो हो & हो हो हो & हो \\
\hline
\end{tabular}

Simple Majority agreement

Significant majority agreement as

Vast majority agreement to

Full majority agreement to

Simple majority disagreement

Significant majority disagreement

Divided (50-50\%) opinion

sub-groups had similar views (vast majority agreement) whereas the ICT-Expert had a significant majority agreement. None of the sub-groups has majority disagreement. The research finds that the opinion on this statement has achieved a very positive consensus on the notion that the open source eLogistic system will benefit SMEs.

\subsubsection{Significant majority agreements}

In this section the authors discuss whether there is any differing views on the statement 'Standardised eLogistics system interfaces can increase efficiency along the supply chain' that achieved a significant majority agreement the authors find that 
Table 3 Trend and possibility of eLogistics systems: vast majority agreement

\begin{tabular}{|c|c|c|}
\hline \multirow[b]{2}{*}{ Participants sub-groups } & \multicolumn{2}{|c|}{$\begin{array}{l}\text { Open source will allow smaller companies access to better quality eLogistics } \\
\text { application }\end{array}$} \\
\hline & Total Participants & Different Levels of Majority Views \\
\hline TLSP & 32 & हो \\
\hline Terminal operator & 8 & को \\
\hline Academic-Research & 22 & हो हो हो \\
\hline Total opinions of different service provisions & 62 & 兒 \\
\hline SME & 23 & हो हो हो \\
\hline Non-SME & 20 & 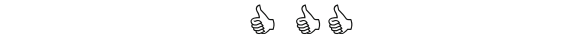 \\
\hline Total opinions of different company sizes & 43 & 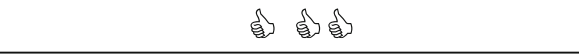 \\
\hline Western EU & 12 & $\Leftrightarrow$ \\
\hline Central EU & 31 & 会自合 \\
\hline Northern EU & 15 & हो \\
\hline Southern EU & 6 & हो \\
\hline Non-EU & 4 & हो $\Rightarrow$ \\
\hline Total opinions of different Geography & 69 & हो \\
\hline ICT Basic & 25 & 家 \\
\hline ICT Competent & 33 & को \\
\hline ICT Expert & 9 & हो \\
\hline Total opinions of different expertise in ICT & 67 & $\Leftrightarrow$ \\
\hline
\end{tabular}

there are some differences (see Table 4) among the sub-groups. For example, the SMEs had a significant majority agreement whereas the Non-SMEs had a vast majority agreement. The TLSP and the Terminal Operator sub-groups had a significant majority agreement whereas the Academic-Researcher had a vast majority agreement. The Geographical sub-groups had a significant majority agreement, except the Northern EU subgroup had a vast majority agreement. But there is a difference among the ICT sub-groups. The ICT-Basic and the ICT-Expert sub-groups had a significant majority agreement whereas the ICT-Competent had a vast majority agreement. None of the sub-groups has majority disagreement. Overall, the authors find that the opinion on this statement has achieved a positive consensus on the necessity and role of a standard eLogistics interface system for an efficient supply chain.

Overall the statement 'In a fragmented market like road freight open standards will allow integration' also had achieved a significant majority agreement by all types of participants groups. The authors detect that there are some differences among the sub-groups. The TLSP and the Terminal Operator sub-groups had a similar (significant majority) agreement whereas the Academic-Researcher sub-group had a higher level of (vast majority) agreement. The SMEs achieved a lower level of (significant majority) agreement compared to the Non-SMEs's who achieved a vast majority agreement. There are some differences among the Geographic subgroups. The Non-EU sub-group had a full agreement; the Northern EU sub-group had a vast majority and the remaining sub-groups had a significant majority agreement. There are some differences among the ICT sub-groups as well. The ICT basic understanding and ICT-Expert subgroups had a similar (simple) majority agreement compared to the ICTCompetent sub-group that had a significant majority agreement. None of the participant group has majority disagreement. Overall, the authors find that the opinion on this statement has achieved a positive consensus on the necessity of an open standard for an integrated eLogistics system, in particular for road freight where many operators are SMEs.

Overall the statement 'Small operators will be forced to use bigger operators' ICT systems' also had achieved a significant majority agreement by all types of participants groups. But there are some differences among the subgroups. The TLSP and the Academic-Researcher subgroups had a similar (significant) majority agreement whereas 
Table 4 Trend and possibility of eLogistics systems: significant majority agreement

\begin{tabular}{|c|c|c|c|c|c|c|}
\hline & $\begin{array}{l}\text { Standardise } \\
\text { interfaces ce } \\
\text { along the su }\end{array}$ & $\begin{array}{l}\text { eLogistics system } \\
\text { increase efficiency } \\
\text { ply chain }\end{array}$ & $\begin{array}{l}\text { In a fragment } \\
\text { road freight o } \\
\text { allow integrat }\end{array}$ & $\begin{array}{l}\text { d market like } \\
\text { on standards will } \\
\text { on }\end{array}$ & $\begin{array}{l}\text { Small operat } \\
\text { use bigger o } \\
\text { systems }\end{array}$ & $\begin{array}{l}\text { S will be forced to } \\
\text { rators' ICT }\end{array}$ \\
\hline Type of participants & $\begin{array}{l}\text { Total } \\
\text { Participants }\end{array}$ & $\begin{array}{l}\text { Different Levels of } \\
\text { Majority Views }\end{array}$ & $\begin{array}{l}\text { Total } \\
\text { Participants }\end{array}$ & $\begin{array}{l}\text { Different Levels } \\
\text { of Majority } \\
\text { Views }\end{array}$ & $\begin{array}{l}\text { Total } \\
\text { Participants }\end{array}$ & $\begin{array}{l}\text { Different Levels } \\
\text { of Majority Views }\end{array}$ \\
\hline TLSP & 32 & $\Leftrightarrow$ & 32 & $\Leftrightarrow$ & 32 & $\Leftrightarrow$ \\
\hline Terminal operator & 9 & $\Leftrightarrow$ & 9 & $\Leftrightarrow$ & 9 & $\Leftrightarrow$ \\
\hline Academic-Research & 22 & की की & 22 & की को & 22 & $\Leftrightarrow$ \\
\hline $\begin{array}{l}\text { Total opinions of different } \\
\text { service provisions }\end{array}$ & 63 & $\Leftrightarrow 1$ & 63 & $\Leftrightarrow \Leftrightarrow$ & 63 & \$. \\
\hline SME & 24 & $\Leftrightarrow$ & 24 & $\Leftrightarrow$ & 23 & 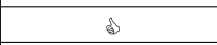 \\
\hline Non-SME & 20 & की की & 20 & की की & 21 & $\Leftrightarrow$ \\
\hline $\begin{array}{l}\text { Total opinions of different } \\
\text { company sizes }\end{array}$ & 44 & a 1 & 44 & $\Leftrightarrow$ & 44 & $\Leftrightarrow$ \\
\hline Western EU & 12 & हो & 12 & ही हो & 12 & की \\
\hline Central EU & 32 & $\Leftrightarrow$ & 32 & $\Leftrightarrow$ & 32 & is \\
\hline Northern EU & 15 & $\Leftrightarrow$ & 15 & की की & 15 & $\Leftrightarrow$ \\
\hline Southern EU & 6 & $\Leftrightarrow$ & 6 & 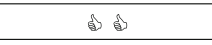 & 6 & (1) \\
\hline Non-EU & 4 & $\Leftrightarrow$ & 4 & $\Leftrightarrow \infty$ & 4 & $\Leftrightarrow$ \\
\hline $\begin{array}{l}\text { Total opinions of different } \\
\text { Geography }\end{array}$ & 69 & $\Leftrightarrow$ & 69 & $\Leftrightarrow \Leftrightarrow$ & 69 & $\Leftrightarrow$ \\
\hline ICT Basic & 26 & $\Leftrightarrow$ & 26 & $\Leftrightarrow \Leftrightarrow$ & 26 & हैक्षी \\
\hline ICT Competent & 33 & (1) 10 & 33 & (2) & 33 & 10 \\
\hline ICT Expert & 9 & $\Leftrightarrow$ & 9 & $\Leftrightarrow$ & 9 & 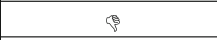 \\
\hline $\begin{array}{l}\text { Total opinions of different } \\
\text { expertise in ICT }\end{array}$ & 68 & $\Leftrightarrow$ & 68 & $\Leftrightarrow$ & 68 & 76 \\
\hline
\end{tabular}

the Terminal Operator sub-groups had a lower level (simple) of majority agreement. The SME sub-groups had a lower level (simple) level of majority compared to the Non-SME subgroup that had a significant majority agreement. There are no major differences among the Geographic sub-groups. There are some major differences among the ICT sub-groups. The ICT basic understanding sub-group had a vast majority and the ICT-Competent sub-group had a significant majority agreement whereas the ICT-Expert sub-group had a simple majority disagreement with the statement. The authors consider that as the statement had achieved a positive consensus that the small operators can be forced to use bigger operators ICT system unless there is an alternative ICT platform.

\subsubsection{Simple majority agreements}

In this section the authors discuss whether there are any differing views on the statement 'It is too difficult to integrate multiple modes of transport in ICT' that achieved a simple majority agreement by all types of participants groups. But the authors find that there are some differences (see Table 5) among the subgroups. The TLSP and the Terminal Operator sub-groups had a similar (simple majority) agreement whereas the AcademicResearcher sub-group had a simple majority disagreement. Both SMEs and Non-SMEs sub-groups had a similar (simple majority) agreement. There are some differences among the Geographic sub-groups. The Non-EU sub-group had a full agreement whereas the Northern EU sub-group had a simple majority disagreement. The remaining sub-groups had a simple majority agreement. There are some major differences among the ICT sub-groups. The ICT-Expert had a vast majority agreement; the ICT-Competent sub-group had a simple majority disagreement whereas the ICT-Basic sub-group had a simple majority agreement. In contrast two sub-groups: Academic-Researcher and Northern EU had majority disagreement. The authors find that although the statement had achieved a majority agreement, in particular taking into account of the views of the TLSP and Terminal Operator who have better practical experience over the Academic-Researcher sub-group.

Overall the statement 'Integration between rail operators will be easier since there are fewer actors' achieved a simple majority agreement by all types of participants groups. But there are some differences among the sub-groups. The Northern EU sub-group had a divided opinion; the ICT-Competent sub-group had a simple majority disagreement and the ICTExpert sub-group had a vast majority agreement with the statement. The authors consider that although the statement had achieved a majority agreement, the message is mixed and not clear enough and further research will be needed.

\subsubsection{Simple majority disagreement}

In this section the authors discuss whether there is any differing views on the statement 'Rail is so monolithic that ICT integration with other modes will fail' that had achieved a simple majority disagreement by all types of participants groups. But there are some differences (see Table 6) among 
Table 5 Trend and possibilities of eLogistics systems: simple majority agreement

\begin{tabular}{|c|c|c|c|c|}
\hline \multirow[b]{2}{*}{ Participants sub-groups } & \multicolumn{2}{|c|}{$\begin{array}{l}\text { It is too difficult to integrate multiple } \\
\text { modes of transport in ICT }\end{array}$} & \multicolumn{2}{|c|}{$\begin{array}{l}\text { Integration between rail operators will be } \\
\text { easier since there are fewer actors }\end{array}$} \\
\hline & Total Participants & $\begin{array}{l}\text { Different Levels of } \\
\text { Majority Views }\end{array}$ & Total Participants & $\begin{array}{l}\text { Different Levels of } \\
\text { Majority Views }\end{array}$ \\
\hline TLSP & 33 & हो & 33 & $\Leftrightarrow$ \\
\hline Terminal operator & 9 & हो) & 9 & $\Leftrightarrow$ \\
\hline Academic-Research & 20 & s & 22 & हो) \\
\hline $\begin{array}{l}\text { Total opinions of different } \\
\text { service provisions }\end{array}$ & 62 & हो) & 63 & $\Leftrightarrow$ \\
\hline SME & 24 & ह) & 23 & $\Leftrightarrow$ \\
\hline Non-SME & 20 & हो) & 21 & $\Leftrightarrow$ \\
\hline $\begin{array}{l}\text { Total opinions of different } \\
\text { company sizes }\end{array}$ & 44 & $\Leftrightarrow$ & 44 & $\hat{\theta}$ \\
\hline Western EU & 12 & $\Leftrightarrow$ & 12 & $\Leftrightarrow$ \\
\hline Central EU & 30 & $\Leftrightarrow$ & 31 & $\Leftrightarrow$ \\
\hline Northern EU & 16 & 得 & 16 & $\Leftrightarrow$ \\
\hline Southern EU & 6 & $\Leftrightarrow$ & 6 & $\Leftrightarrow$ \\
\hline Non-EU & 3 & $\Leftrightarrow \Leftrightarrow$ & 4 & हो \\
\hline Total Geographic opinions & 67 & $\Leftrightarrow$ & 69 & $\Leftrightarrow$ \\
\hline ICT Basic & 25 & $\Leftrightarrow$ & 25 & $\Leftrightarrow$ \\
\hline ICT Competent & 23 & $\Leftrightarrow$ & 34 & 住 \\
\hline ICT Expert & 8 & हो & 9 & हो हो हो \\
\hline Total ICT wise opinions & 56 & $\Leftrightarrow$ & 68 & $\Leftrightarrow$ \\
\hline
\end{tabular}

the sub-groups. The Northern-EU sub-group had a significant majority disagreement; the Terminal Operator sub-group had a vast majority disagreement; the Southern-EU had divided opinion whereas the Non-EU sub-group had a significant majority agreement with the statement. The remaining sub-groups had a simple majority disagreement. The authors consider that although the statement had achieved a majority disagreement, the message is mixed and not clear enough and thus further research will be needed.

Similarly the statement 'German ICT will dominate eLogistics in Europe as German logistics continues to dominate' had achieved a simple majority disagreement by all types of participants groups. But there are some differences among the sub-groups. The Terminal Operator sub-group had a simple majority agreement and the Southern-EU groups had a significant majority agreement whereas the Western EU, the Non-EU and the ICT-Expert sub-groups had a significant majority disagreement with the statement. The remaining sub-groups had a simple majority disagreement. The authors consider that although the statement had achieved a majority disagreement, the message is mixed and not clear enough and thus further research will be needed.

\subsubsection{Additional research questions/statement expressed by the participants}

The participants of the online survey added a large number of statements, listed in Annex 1, on the trends, possibilities, risks, opportunities, actors, impacts, and vision of an integrated eLogistics system. The authors consider that these statements are very important contribution to the future research in the field.

\section{3 eLogistics applications}

The survey included one question "Please detail which applications you use to support freight transport activities and also the supply and support of applications". The question provided thirteen different eLogistics applications (discussed below). Table 7 provides the summary of the general opinions on the eLogistics applications, their sources and hardware platform.

\subsubsection{General findings}

The general findings on the functional areas of eLogistics applications are discussed below. 
Table 6 Trend and possibilities of eLogistics system: simple majority disagreement

\begin{tabular}{|c|c|c|c|c|}
\hline \multirow[b]{2}{*}{ Participants sub-groups } & \multicolumn{2}{|c|}{$\begin{array}{l}\text { German ICT will dominate eLogistics in } \\
\text { Europe as German logistics continues to } \\
\text { dominate }\end{array}$} & \multicolumn{2}{|c|}{$\begin{array}{l}\text { Rail is so monolithic that ICT integration } \\
\text { with other modes will fail }\end{array}$} \\
\hline & Total Participants & $\begin{array}{l}\text { Different Levels of } \\
\text { Majority Views }\end{array}$ & Total Participants & $\begin{array}{l}\text { Different Levels of } \\
\text { Majority views }\end{array}$ \\
\hline TLSP & 31 & 解 & 33 & 德 \\
\hline Terminal operator & 9 & $\Leftrightarrow$ & 9 & 㲅但 \\
\hline Academic-Research & 20 & 得 & 22 & 德 \\
\hline $\begin{array}{l}\text { Total opinions of different service } \\
\text { provisions }\end{array}$ & 60 & 得 & 64 & 但 \\
\hline SME & 24 & 得 & 24 & 得 \\
\hline Non-SME & 19 & 得 & 21 & 㣪 \\
\hline Total opinions of different company sizes & 43 & 5 & 45 & 幖 \\
\hline Western EU & 10 & 4 & 12 & 你 \\
\hline Central EU & 31 & 幖 & 32 & 德 \\
\hline Northern EU & 15 & 鱼 & 16 & 4 \\
\hline Southern EU & 6 & $\Leftrightarrow$ & 6 & $\Leftrightarrow$ \\
\hline Non-EU & 4 & 但 & 4 & $\Leftrightarrow$ \\
\hline Total opinions of different Geography & 66 & 但 & 70 & 传 \\
\hline ICT Basic & 26 & 得 & 26 & 解 \\
\hline ICT Competent & 31 & 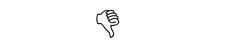 & 34 & 得 \\
\hline ICT Expert & 8 & 85 & 9 & 得 \\
\hline Total opinions of different expertise in ICT & 65 & 得 & 69 & 解 \\
\hline
\end{tabular}

Organisational management systems A majority (61.11\%) of the respondents use eLogistics applications for their "order management" where the use of the "in-house systems" is at the top $(45.83 \%)$ followed by the proprietary package $(33.33 \%)$. A half of $(50 \%)$ of the eLogistics application users use their "own hardware" platform followed by the "internet" platform (19.56\%).

Booking For booking purposes the majority (51.39\%) of the respondents use eLogistics applications where the use of the "in-house" systems is at the top (47.50\%) followed by the proprietary package $(27.50 \%)$. About $45.95 \%$ of the eLogistics application users use their "own hardware" platform followed the "internet" platform $(21.62 \%)$

Invoicing systems For invoicing systems the majority (63.87\%) of the respondents use eLogistics applications where the use of the "in-house" systems is at the top $(52.27 \%)$ followed by the proprietary package $(38.64 \%)$. The majority $(68.18 \%)$ of the eLogistics application users use their "own hardware" platform followed by "Supplier hardware" platform (13.63\%).
Cargo monitoring systems The majority (54.17\%) of the respondents do not use the eLogistics applications for cargo monitoring systems. However, the use of the "in-house" systems and "proprietary package" systems are equal $(35.13 \%)$. On the other hand, a significant proportion $(32.43 \%)$ of these users use their "own hardware" platform followed the "internet" platform $(24.32 \%)$.

Vehicle tracking and tracing systems Alike the cargo monitoring system, the majority (56.50\%) of the respondents do not use the eLogistics applications for vehicle tracking and tracing activities. However, the use of "proprietary package" is at the top $(44.11 \%)$ followed by the "in-house" $(32.35 \%)$. On the other hand, $27.27 \%$ of these users use their "own hardware" platform followed by "Supplier hardware" platform (18.18\%).

Route guidance systems- GPS The majority (63.88\%) of the respondents do not use the eLogistics applications for the route guidance system. However, the use of the "inhouse" and "proprietary package" systems is almost equal (33\%). Similarly no platform has a major dominance over 
Table 7 eLogistics applications: use, origin of applications and hardware platform

\begin{tabular}{|c|c|c|c|c|c|c|c|c|c|c|c|}
\hline \multirow[t]{2}{*}{ eLogistics applications } & \multicolumn{2}{|c|}{ Used? } & \multicolumn{4}{|c|}{ What is the origin of the application? } & \multicolumn{5}{|c|}{ What is the hardware platform? } \\
\hline & Yes & No & $\begin{array}{l}\text { Proprietary } \\
\text { Package }\end{array}$ & $\begin{array}{l}\text { In-house } \\
\text { system }\end{array}$ & $\begin{array}{l}\text { Open } \\
\text { source }\end{array}$ & Unknown & $\begin{array}{l}\text { Own } \\
\text { hardware }\end{array}$ & $\begin{array}{l}\text { Supplier } \\
\text { hardware }\end{array}$ & $\begin{array}{l}\text { Third party } \\
\text { hardware }\end{array}$ & $\begin{array}{l}\text { Internet } \\
\text { platform }\end{array}$ & Unknown \\
\hline Order management & 44 & 28 & 16 & 22 & 1 & 9 & 23 & 4 & 4 & 9 & 6 \\
\hline Booking & 37 & 35 & 11 & 19 & 1 & 9 & 17 & 5 & 1 & 8 & 6 \\
\hline Invoicing systems & 46 & 26 & 17 & 23 & 0 & 4 & 30 & 6 & 1 & 2 & 5 \\
\hline Cargo monitoring & 33 & 39 & 13 & 13 & 3 & 8 & 12 & 5 & 3 & 9 & 8 \\
\hline Vehicle tracking and tracing & 31 & 41 & 15 & 11 & 2 & 6 & 9 & 7 & 6 & 6 & 5 \\
\hline Route guidance system-GPS & 26 & 46 & 8 & 9 & 2 & 8 & 8 & 6 & 2 & 5 & 6 \\
\hline Multimodal route planning & 16 & 56 & 5 & 6 & 2 & 7 & 6 & 3 & 2 & 2 & 7 \\
\hline Terminal operation optimisation & 13 & 59 & 4 & 5 & 1 & 8 & 7 & 1 & 1 & 0 & 8 \\
\hline Transport statistics and assessment & 34 & 38 & 6 & 19 & 1 & 6 & 23 & 2 & 3 & 0 & 6 \\
\hline Fleet management & 23 & 49 & 4 & 11 & 3 & 7 & 13 & 2 & 1 & 2 & 7 \\
\hline Decision support & 22 & 50 & 8 & 8 & 3 & 7 & 13 & 2 & 2 & 1 & 9 \\
\hline Electronic Data Interchange (EDI) & 33 & 39 & 12 & 10 & 4 & 6 & 15 & 3 & 5 & 4 & 7 \\
\hline E-commerce applications & 18 & 54 & 6 & 5 & 4 & 8 & 6 & 2 & 1 & 7 & 7 \\
\hline
\end{tabular}

the platforms ("own hardware" - $29.63 \%$, the supplier hardware $-22.22 \%$ and the internet platform $-18.52 \%$ ).

Multimodal route planning An overwhelming majority $(77.78 \%)$ of the respondents do not use the eLogistics applications for the multimodal route planning. About one third of the users use the "in-house" applications followed by the "proprietary package" system (20\%). On the other hand, about a third of these users use their "own hardware" platform followed by "Supplier hardware" platform (15\%).

Terminal operations optimisation systems An overwhelming majority $(81.94 \%)$ of the respondents do not use the eLogistics applications for terminal operation optimisation. About one fourth of the users use the "in-house" applications followed by the "proprietary package" system $(22.22 \%)$. On the other hand, about $41 \%$ of these users use their "own hardware" platform.

Transport statistics and assessment systems The majority $(52.78 \%)$ of the respondents do not use the eLogistics applications for transport statistics assessment system. But the majority (59.37\%) of these users use the "in-house" applications followed by the "proprietary package" system $(18.75 \%)$. On the other hand, the majority $(67.65 \%)$ of these users use their "own hardware" platform.

Fleet management systems The majority $(68 \%)$ of the respondents do not use the eLogistics applications for transport resource allocations (fleet management) system. But about $44 \%$ of these users use the "in-house" applications followed by the "proprietary package" system (16\%). On the other hand, the majority (52\%) of these users use their "own hardware" platform.

Decision support systems An overwhelming majority $(69.44 \%)$ of the respondents do not use the eLogistics applications for the decision support system. However, the use of the "in-house" and the "proprietary package" systems is equal $(30 \%)$. On the other hand, about $48 \%$ of these users use their "own hardware" platform.

Electronic Data Interchange (EDI) The majority (54.17\%) of the respondents do not use the eLogistics applications for the electronic data interchange (EDI). However, about $37.50 \%$ of these users use "proprietary package" applications followed by the "in-house" system $(31.25 \%)$. On the other hand, about $44 \%$ of these users use their "own hardware" platform.

e-Commerce applications The majority (75\%) of the respondents do not use the eLogistics applications for eCommerce applications. However, about $26 \%$ of these users use the "proprietary package" followed by the "inhouse" applications system (16\%). On the other hand, about $30 \%$ of these users use the internet platform followed by $26 \%$ use of the "own hardware" platform.

The participant added further six areas of eLogistics applications that are listed in annex 1 .

\subsubsection{The use of eLogistics applications: varying views}

In this section the authors explore whether there is any differing view among the sub-groups. Table 8 summarises the sub-group wise views with to number of participants. 
The authors have detected some differences of views on the use of eLogistics applications. The results are presented in Table 8 showing that a majority (more than $50 \%$ ) of the SME sub-group uses the eLogistics applications in the following functional areas: Order Management Systems, Booking, Invoicing, Transport Statistics and Assessment Systems and EDI. But the Non-SME sub-group had more usage of eLogistics applications: Order Management Systems, Booking, Invoicing, Cargo Monitoring Systems, Vehicle Tracking and Tracing, Transport Statistics and Assessment Systems and EDI. The TLSP even have a higher (than the Non-SME group) usage: Order Management Systems, Booking, Invoicing, Cargo Monitoring Systems, Vehicle Tracking and Tracing, Route Guidance Systems- GPS, Transport Statistics and Assessment Systems and EDI as well. The Terminal Operators have usage of eLogistics system in the following six functional areas: Order Management Systems, Booking, Invoicing, Cargo Monitoring Systems, Transport Statistics and Assessment Systems and EDI. The Shippers have a limited usage of eLogistics applications: only in Order Management Systems and Invoicing. The authors find that the similarity among the usage of eLogistics applications of the Non-SME, the TLSP and the Terminal Operator groups is possibly due to the fact that the majority of the TLSP and Terminal Operator participants belong to Non-SME group. And these groups have higher technical and financial capacity and skills to use the eLogistics applications. On the other hand the lower usage of eLogistics applications by the SME (and the Shipper) sub-group is possibly due the fact that they lack technical and final capacity and skills.

\section{Summary}

eLogistics is an emerging terminology within the logistics field. There is not yet a widely accepted definition. The current research attempted to define it firstly by literature reviews of books and online sources in collaboration with the KOMODA project, and then seeking opinion on it through an online survey. The online survey finds that the proposed definition ('a set of activities based on using ICT systems and tools, as well as the Internet, as the main communication medium in order to maintain logistics processes) has a vast majority agreement. But there are wide variations of views along the sub-groups of the participants. Some sub-groups have full agreement, some have vast or significant or simple agreement. But there is a disagreement as well, by the Authorities sub-group, although with a small sample size. So, the authors suggest that the opinion of the Authorities sub-group can be discarded.

The statement 'The definition is widely applicable in the freight and logistics sector' has also achieved a vast majority agreement'. There are some variations of views (from full agreement to simple majority agreement) among the subgroups. But there is no majority disagreement. But surprisingly the Authorities sub-group has a vast majority agreement, although they did not agree with the definition. So, the authors suggest that the opinion of the Authorities sub-group can be discarded (due to contradictory opinion as well as small sample size). So the authors are in the opinion that this definition has achieved a majority consensus and it has wide applicability.

The statement 'eLogistics is poorly understood or defined in the freight and logistics sector' has achieved a simple

Table 8 The usage of eLogistics applications: varying views

\begin{tabular}{|c|c|c|c|c|c|}
\hline The Use of eLogistics applications & $\begin{array}{l}\text { SME No. } \\
\text { (percent) }\end{array}$ & $\begin{array}{l}\text { Non-SME No. } \\
\text { (percent) }\end{array}$ & $\begin{array}{l}\text { TLSP No. } \\
\text { (percent) }\end{array}$ & $\begin{array}{l}\text { Terminal Operator } \\
\text { No. (per cent) }\end{array}$ & $\begin{array}{l}\text { Shipper No. } \\
\text { (percent) }\end{array}$ \\
\hline Order management system & $20(77)$ & $17(81)$ & $29(83)$ & $5(56)$ & $3(100)$ \\
\hline Booking (customs, carriers) & $15(58)$ & $16(76)$ & $24(69)$ & $6(66)$ & $1(33)$ \\
\hline Invoicing systems & $24(92)$ & $18(86)$ & $33(94)$ & $7(78)$ & $2(66)$ \\
\hline Cargo Monitoring systems & $11(42)$ & $17(81)$ & $19(54)$ & $8(88)$ & $1(33) \%$ \\
\hline Vehicle Tracking and tracing systems & $12(46)$ & $12(57)$ & $19(54)$ & $4(44)$ & $1(33)$ \\
\hline Route guidance system-GPS & $11(42)$ & $9(43)$ & $16(46)$ & $4(44)$ & - \\
\hline Multimodal Route planning & $6(23)$ & $3(14)$ & $8(23)$ & $1(11)$ & - \\
\hline \multicolumn{6}{|l|}{ Terminal operation } \\
\hline Optimisation systems & $5(19)$ & $7(33)$ & $8(23)$ & $4(44)$ & - \\
\hline Transport statistics and assessment system & $16(62)$ & $15(71)$ & $24(69)$ & $7(78)$ & - \\
\hline Transport resources allocations (fleet management systems) & $8(31)$ & $10(48)$ & $14(40)$ & $4(44)$ & - \\
\hline Decision support systems & $9(35)$ & $8(38)$ & $13(37)$ & $4(44)$ & - \\
\hline Electronic data interchange (EDI) & $14(54)$ & $16(76)$ & $22(63)$ & $7(78)$ & $1(33)$ \\
\hline Ecommerce applications & $6(23)$ & $6(29)$ & $10(29)$ & $2(22)$ & $0.00 \%$ \\
\hline Total participants & $26(100)$ & $21(100)$ & $35(100)$ & $9(100)$ & $3(100)$ \\
\hline
\end{tabular}


majority agreement. There are some differences of opinion on this statement. Some sub-groups have a significant majority agreement and other have a simple majority agreement. But there are divided opinions as well. The authors suggest from these varying views that there is a mixed feeling about the terminology eLogistics in the logistics sector. In the mean time a new terminology 'e-Freight' [2] has emerged in the EU policy area, and also existing terms such as e-commerce or e-business seem to have wider use. It is too early to suggest that the term will be used widely, although the survey suggests it has a wide utility.

To explore the current trends and possibilities of eLogistics systems and applications, opinion were sought on eight statements. The statement 'Open source will allow smaller companies access to better quality applications', achieved a vast majority agreement consensus, although there are some differences of views among the sub-groups. There is no majority disagreement. So the authors suggest that the SMEs will hugely benefit from an open source eLogistics platform and national government and European Commission should provide financial support to establish and run such open source platform either by associations or trade bodies of the SMEs or third parties.

The statement 'Standardised eLogistics system interfaces can increase efficiency along the supply chain' achieved a significant majority agreement; there are some variations of views (from vast to significant). But there is no majority disagreement. The authors recommend that the standard eLogistics system interface will be helpful to achieve an efficient eLogistics system. The open eLogistics platforms (recommended in previous paragraph) should use standardised system interfaces.

The statement ('In a fragmented market like road freight open standards will allow integration') have achieved a significant majority agreement as well, although there are some variations of views (from full agreement to significant majority agreement). But there is no majority disagreement. The authors think that the integration of the SMEs will be easier, if an open eLogistics system platform can be developed with standardised interfaces.

The statement 'Small operators will be forced to use bigger operators' ICT systems' also achieved a significant majority agreement, although there are some varying views (from a vast majority to a simple majority agreement) among the sub-groups, although one sub-group (ICT-Expert) has got majority disagreement. However the authors suggest that the necessity of the development of an open eLogistics platform for the usage of SMEs is even more evident to eliminate the fear of forceful integration.

The statements 'It is too difficult to integrate multiple modes of transport in ICT' achieved a simple majority agreement. But there are major variations of opinions (from full agreement to simple majority disagreement) among the sub- groups. The authors suggest that the consensus on the notion is not clear enough and can be explored in the future research.

The statement 'Integration between rail operators will be easier since there are fewer actors', have achieved a simple majority agreement, although there are some differences of views (from full agreement to divided opinion and majority disagreement). The authors suggest that the consensus on the notion is not clear enough and can be explored in the future research.

The authors suggest from these responses that the integration in ICT and Transport Logistics will face similar problems to the physical interoperability of modes: although the authors don't know if this difficulty is systematic within ICT itself or a cultural or organisational one. Integration through dominance, e.g. absorption into bigger operator systems seems logical, but the authors can also suggest that this may lead to a burden to SMEs who wish to trade with multiple bigger organisations and therefore support multiple platforms. Lastly there is optimism that ICT integration will be easier in rail due to the limited number of players. Certainly projects such as RETRACK [9] have shown that ICT integration in the smaller railway undertakings sector is a complex and dynamic one, it has yet to be shown if large scale integration such as that proposed by the INEGRAIL project [6] can be achieved, fewer players or not.

The statements 'Rail is so monolithic that ICT integration with other modes will fail' achieved a simple majority disagreement, although there are some diverse and extreme views (from a significant majority agreement to a vast majority disagreement or a significant majority disagreement or a divided opinion). In general it appears that the respondents seem confident that the rail ICT can integrate with other modes (which are somewhat at odds with previous statement: 'It is too difficult to integrate multiple modes of transport in ICT' that achieved a simple majority agreement).

The statement 'German ICT will dominate eLogistics in Europe as German logistics continues to dominate' also achieved a simple majority disagreement, although there are some differing views (from a significant majority agreement to a simple majority disagreement) among the subgroups. The authors find that although German logistics dominance in the EU logistics area is a reality and is growing, the German ICT industry will not dominate similarly.

The study finds that eLogistics applications are generally used by majority of the participants in three areas: order management systems, booking (customers, carriers) and invoicing systems. They are less used in the remaining areas, although these areas are core activities of logistics sectors. There is a big difference in the use of eLogistics applications among different groups. The Non-SMEs have usage of eLogistics applications in a higher number of areas than the SMEs. The SMEs need to upgrade their technical and financial capability and skills to achieve higher usage of eLogistics applications. Similarly the TLSP have usage of 
eLogistics applications in a higher number of areas than the Terminal Operator or the Shipper sub-groups. There is a similarity of use of eLogistics applications (a majority use in seven similar areas) between Non-SME and TLSP subgroups, possibly due to the fact that most of the TLSPs are Non-SMEs. It can be noted that the shipper group has a very small sample and thus it was disregarded.

\section{Conclusion}

The authors conclude from the findings of the online survey is that there is a clear belief from across the academic, researchers, experts and practitioners that open source, open standards and standardised system interfaces will support increased supply chain efficiency through integration and with access to SMEs as well as larger players. This supports the EU policy objectives in the Freight Logistics Action Plan [5] and elsewhere to promote such open standards and interfaces. Such work has been explored in other projects such as Freightwise [13], Smart-CM, Smartfreight, e-Freight and elsewhere [12].

The development and running of an eLogistics platform is costly for SMEs. The authors recommend that such platform can be developed through funding by national governments and/or European Commission. The running and maintenance of such a platform can be done by an association of relevant SMEs or a third party with a small contribution (or fee) by the participating SMEs.

The authors commend this paper as a small contribution to the knowledge in the field. This paper has explored a small subset of the subject of ICT and Transport Logistics. It is a first step of an ongoing research. The authors expect that a large number of issues on eLogistics systems, applications and functional areas raised are suggested (listed in annex 1) by the survey participants that will be explored in the future research and the findings will be reported in another paper.

\begin{abstract}
Acknowledgments The authors would like to thank three anonymous peer reviewers for their invaluable positive criticisms that enriched the quality of the paper. The authors would like to thank the European Commission for part-funding the research under the Framework Programme seven, first call, for the project KOMODA: Comodality- towards optimised integrated chains in freight transport logistics. The authors would also like to thank all KOMODA project partners and survey participants, without whom the research would not be a success, for taking part in the survey and generating opinions in the research. However, the content and the opinion expressed in this article are the full responsibility of the authors.
\end{abstract}

Open Access This article is distributed under the terms of the Creative Commons Attribution License which permits any use, distribution and reproduction in any medium, provided the original author(s) and source are credited.

\section{References}

1. Bristol Online Survey (BOS) (2010) In http://www.survey.bris. ac.uk/ last visited on 16-08-2010

2. E-Freight (2010) An integrated project within the EC 7th Framework Programme, in http://www.efreightproject.eu/, last visited on 16-08-2010

3. eLogistics Guide Dormund (2010) Fraunhofer Institute for material flow and logistics, last visited on 26.07.2010 available at eLogistics Guide Dormund, 2010

4. Elogistics-ltd.com (2010) An online source last visited on 26.07.2010 available at http://www.elogistics-ltd.com/en/ueberuns.asp

5. European Commission (2007) Freight logistics action plan, communication from the commission, Brussels XXX, COM (2007) yyy, in http://ec.europa.eu/transport/logistics/freight_logistics action_plan/doc/action_plan/2007_com_logistics_action_plan_ en.pdf, last visited on 16-08-2010

6. INTEGRAIL (2010) INTELLigent integration of RAILway systems, in http://www.integrail.info/

7. KOMODA (2010) Co-modality-towards optimised integrated cahins in freight transport logistics, in http://www.komodaproject. ]com/, last visited on 16-08-2010

8. Mangan J, Lalwani C, Butcher T (2008) Global logistics and supply chain management. John Wiley and Sons ltd, Chippenham

9. RETRACK (2010) Reorganisation of transport networks by advanced rail freight concepts, in http://www.retrack.eu/, last visited on $16-08-2010$

10. Rushton A, Croucher P, Baker P (2009) The handbook of logistics and distribution management, 3rd edn. Kogan Page, London

11. Langley CJ, Coyle JJ, Gibson BJ, Novack RA, Bardi EJ (2008) Managing supply chains a logistics approach, 8th edn. South Western Cengage Learning

12. Rittscher, Husagic, Mueller, Gropp (2007) RETRACK D2.2-PublicState of Art ICT-Final v2.5, Essen, http://www.retrack.eu/download ables/Deliverables/D2.2-Public-State\%20of\%20Art\%20ICTFinal\%20v2.5-Husagic-18122007.pdf

13. Di Re S, Campagna A, Nanni U (2009) A reference architecture for freight transport management systems, Rome, 2009, http:// www.freightwise.info/cms/Content/download/A-reference-archi tecture-for-freight-transport-management-systems.pdf

14. Zang L-P, Yadav P, Change H (2010) ELIPF: an e-Logistics process integration framework based on web services. An online paper last visited 26.07.2010 available at http://www.research. ibm.com/people/b/bth/OOWS2001/zhang.pdf

\section{Selected related research projects}

15. Freightwise, http://www.freightwise.info

16. Smart-CM, http://www.smart-cm.eu/

17. Smartfreight, http://www.smartfreight.info/index.htm 